\title{
Patterns of Transmission and Sources of Infection in Outbreaks of Human Toxoplasmosis
}

\author{
Fernanda Pinto-Ferreira, Eloiza Teles Caldart, Aline Kuhn Sbruzzi Pasquali, \\ Regina Mitsuka-Breganó, Roberta Lemos Freire, Italmar Teodorico Navarro
}

\begin{abstract}
We report on apparent temporal progression of probable sources of infection and transmission routes for global human toxoplasmosis outbreaks as described in published articles. We searched the Scientific Electronic Library Online, Web of Science, PubMed, and Scopus databases for articles on Toxoplasma, toxoplasmosis, and outbreaks. We found that transmission routes for Toxoplasma gondii varied by decade. In the 1960s and 1990s, toxoplasmosis outbreaks mainly occurred through ingestion of cysts in meat and meat derivatives; in the 1980s, through milk contaminated with tachyzoites; in 2000, due to the presence of oocysts in water, sand, and soil; and in 2010, due to oocysts in raw fruits and vegetables. Our study suggests a possible change in the epidemiology of reported toxoplasmosis outbreaks. Because of this change, we suggest that greater attention be paid to the disinfection of vegetables, as well as to the quality of water used for drinking and irrigation.
\end{abstract}

$\mathrm{T}$ oxoplasmosis is a zoonotic disease caused by the protozoan Toxoplasma gondii of the phylum Apicomplexa, an obligate intracellular parasite with a worldwide distribution that infects mammals and birds (1). Warm-blooded animals serve as intermediate hosts for $T$. gondii, but felids are its only definitive host and shed oocysts that result in environmental contamination (2).

Because of high exposure to T. gondii around the world, humans have a high serologic prevalence, which varies between $10.0 \%$ and $97.4 \%$ in the adult population. However, cases of clinical disease are less frequent (3). Environmental conditions, cultural and eating habits, and fauna are factors in the variability and prevalence of toxoplasmosis in different geographic areas (4). Transmission mainly occurs through the ingestion of water, vegetables, or soil contaminated with oocysts (sporozoites) or raw or undercooked meat containing viable tissue cysts (bradyzoites), characterizing this disease as a foodborne zoonosis (3).

Author affiliations: State University of Londrina, Londrina, Brazil (F. Pinto-Ferreira, E.T. Caldart, R. Mitsuka-Breganó, R.L. Freire, I.T. Navarro); Unoesc, Santa Catarina, Brazil (A.K.S. Pasquali)

DOI: https://doi.org/10.3201/eid2512.181565
Better understanding of the patterns of occurrence of human toxoplasmosis outbreaks could lead to more effective and targeted prevention and control measures. We report a possible temporal progression of the probable sources of infection and transmission routes described in articles on human toxoplasmosis outbreaks throughout the world from the 1960s through March 2018.

\section{Materials and Methods}

We performed a systematic review by searching the Scientific Electronic Library Online (Scielo), Web of Science, PubMed, and Scopus databases by using the keywords "Toxoplasma AND outbreak OR toxoplasmosis AND outbreak." During February-March 2018, we collected data on published toxoplasmosis outbreaks in humans since 1967, when the first relevant article on human infection was published (5).

We reviewed published articles to look for changes in the pattern of transmission routes and sources of infection for toxoplasmosis outbreaks in humans around the world. We included articles with at least the abstract in English or Portuguese. We excluded articles on outbreaks of toxoplasmosis in nonhuman species and studies without information about the transmission route.

For each outbreak report, we extracted the year, country of outbreak occurrence, probable source of transmission, number of affected persons, and the affected group. By reviewing the probable source of infection and transmission route defined by the authors of the selected papers, we inferred the parasitic form involved in each case or outbreak report. We used Mendeley (Elsevier, https://www. mendeley.com) software to organize, exclude, and select references. We used Epi Info 3.5.4.4 (6) software to tabulate variables obtained from information extracted from the selected articles.

We performed statistical analyses by using $\chi^{2}$ or Fisher exact tests in R 3.4.1 (http://www.R-project.org) and performed multiple correspondence with the FactoMineR package (http://factominer.free.fr). We chose this technique because it does not rely on statistical tests and provides 
visualization of the most relevant relationships in a large set of variables (7). It also helps visualize the multivariate relationship between categories of different variables; the geometric proximity of variables in the graph suggests their possible association.

\section{Results}

We found a total of 573 articles: 10 in Scielo, 224 in Web of Science, 83 in PubMed, and 256 in Scopus. We excluded articles that did not contain the likely route of transmission, as well as duplicate or incomplete articles, such as those missing titles, authors, or abstracts. We also excluded articles we could not access because they were not available on the Internet or in other sources. For analysis, we selected 33 articles covering 34 reports of outbreaks of acute toxoplasmosis (Figure 1; Appendix Table, https://wwwnc.cdc. gov/EID/article/25/12/18-1565-App1.pdf).

We plotted the geographic distribution of the selected outbreaks on a map (Figure 2). The highest concentration of reported outbreaks, 25/34 (73.5\%), occurred in the Americas; Brazil had 35.3\% (12/34) of the published outbreaks.

The incidence of cyst-related outbreaks from contaminated meat and its derivatives was $47.1 \%(16 / 34)$, and oocysts were implicated in $44.1 \%(15 / 34)$ of the outbreaks. Transmission through the intake of oocysts in water occurred with a frequency of $20.6 \%(7 / 34)$, through contact with sand and soil with a frequency of $17.6 \%(6 / 34)$, and through consumption of vegetables with a frequency of $5.9 \%(2 / 34)$. Tachyzoites in raw milk caused $8.8 \%(3 / 34)$ of outbreaks. Approximately 1,416 persons were affected in the 15 outbreaks of toxoplasmosis from oocysts (sporozoites), 290 in the 16 outbreaks from tissue cysts (bradyzoites), and 15 in the 3 outbreaks from tachyzoites.

We did not observe a statistical significance in the variables extracted from the articles. Our multiple correspondence analysis shows outbreaks mainly occurred through the ingestion of cysts in meat and its derivatives in the 1960s and 1990s. In the 1980s, milk contaminated with tachyzoites was the primary transmission route. In 2000, outbreaks were caused by oocysts in water and contact with feline feces. Since 2010, outbreaks related to oocyst intake from raw vegetables have increased (Figure 3 ).

\section{Discussion}

Our study had several limitations. Many outbreaks are published only in gray literature, such as in nonindexed journals, on government websites, and in conference abstracts, rather than in peer-reviewed journals such as those we searched. Our search was limited to articles with at least the abstract written in Portuguese or English. Reports had long lag time between an outbreak and the publication of ts occurrence, ranging from 3-7 years. Transmission routes, which can be measured only by means of epidemiologic investigation $(8,9)$, were not always defined in the reports. Although our review searched reports from scientific literature worldwide, it demonstrates much of the reality in Brazil, where we saw the most outbreak reports and the highest numbers of affected persons (776/1,721).

The major clones of $T$. gondii, genotypes I, II, and III, described in the literature differ in virulence and epidemiology (10-13). We did not see a clear domain of any genotype in the United States, even though some have relatively higher frequencies (12). In Brazil, the seroprevalence of toxoplasmosis in humans ranges from $21.5 \%$ to $97.4 \%$ (14), with more frequent occurrences of atypical genotypes, which might explain reports of the more severe form of the disease (15) and the larger numbers of affected persons from this country. In fact, the 2 largest outbreaks of human toxoplasmosis we saw occurred in Brazil. In 2001, an outbreak in Santa Isabel do Ivaí in Paraná State involved $>400$ persons and was attributed to contamination of the municipal water supply network (16). Another outbreak occurred in Santa Maria in Rio Grande do Sul State in 2018 and affected $>900$ persons; the cause has yet to be determined (17).

Oocysts and cysts are the most frequent parasitic form of $T$. gondii transmitted to humans (8). According to our results, before 1990, cysts consumed in meat were the main biologic form infecting humans. Beef was the suspected vehicle of transmission in 3 outbreaks: 1 in the United States that affected 5 persons, 1 in Brazil that affected 6 persons, and 1 in Brazil that affected 99 (Appendix). However, because cattle have a low ability to form tissue cysts, beef has less epidemiologic value (Appendix).

Human dietary preferences also can facilitate infection by $T$. gondii (4), especially in raw or undercooked meat.

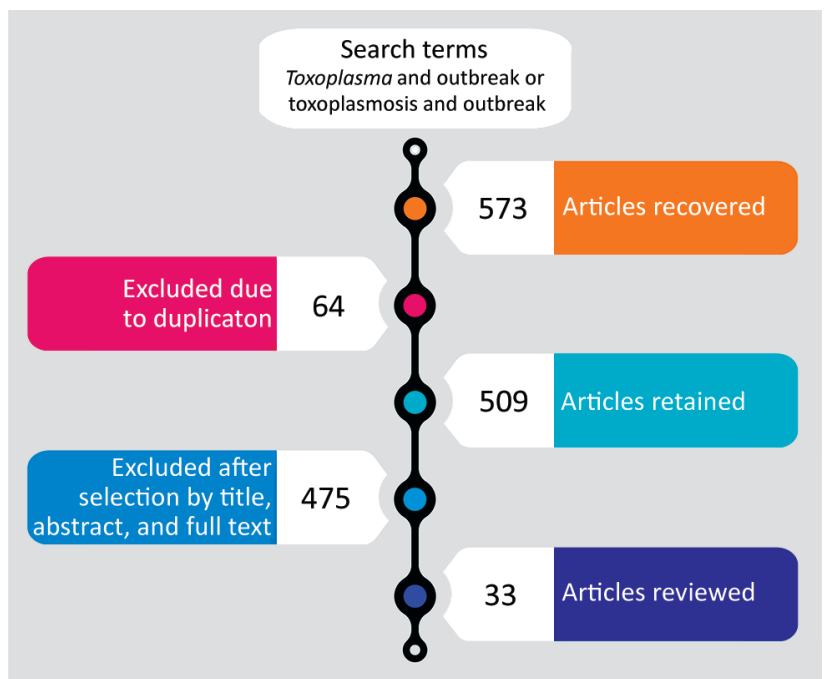

Figure 1. Selection process for articles for systematic review of reports of outbreaks of human toxoplasmosis throughout the world during 1967-March 2018. 


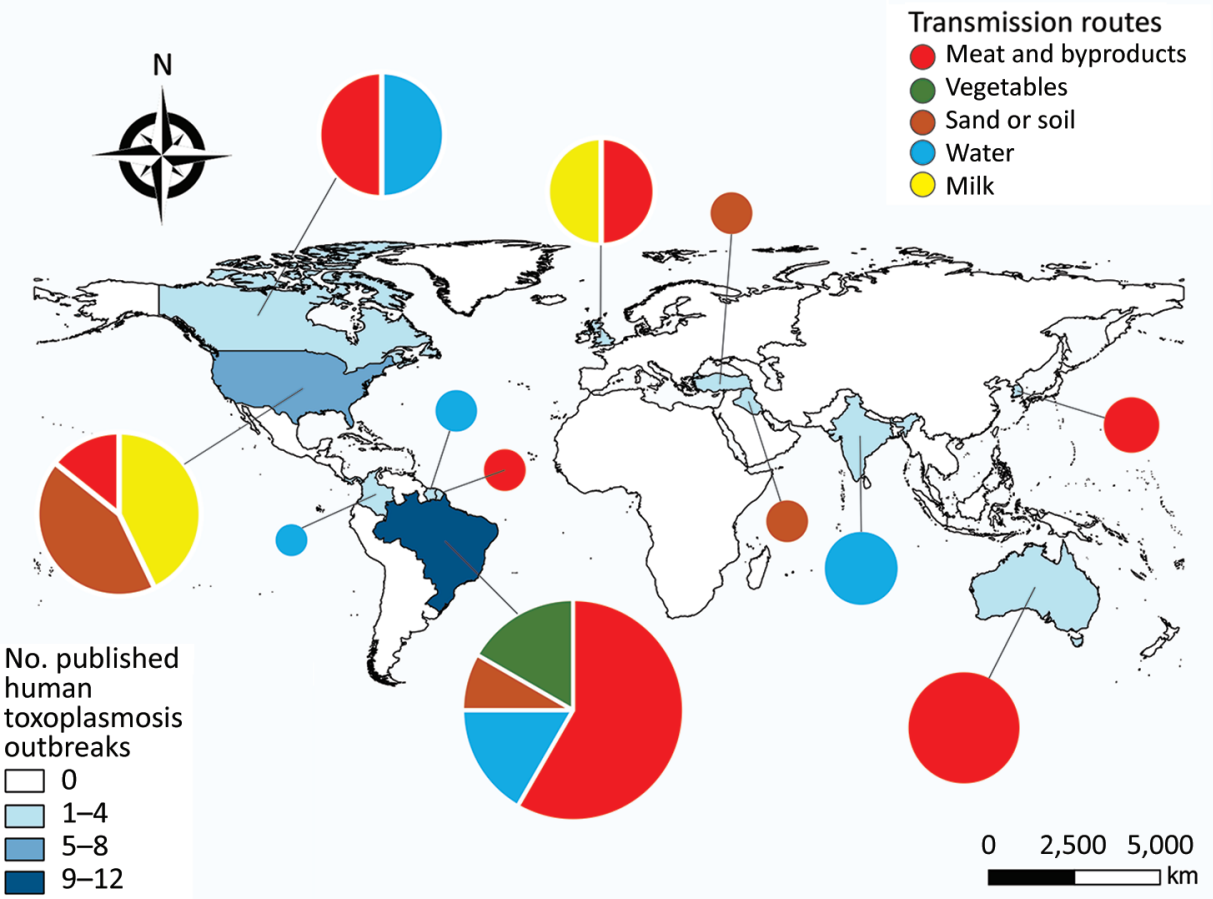

Figure 2. Geographic distribution of 34 outbreaks of human toxoplasmosis worldwide as cited in reports published during 1967-March 2018. Probable and known transmission routes are indicated by color. Circle size corresponds to the number of outbreaks.
For example, consumption of kibbe, a traditional dish in the Middle East made from raw lamb meat, was the cause of 5 outbreaks between 1975 and 2006, 2 in $\operatorname{Brazil}(18,19)$ and 1 each in England (20), the United States (21), and Australia (22).

Because tissue cysts are sensitive to heat (23), properly cooked meat poses less of a risk for $T$. gondii infection in humans. In the 1990s, the government of Brazil implemented a prevention project for another parasitic infection, teniasis-cysticercosis. The project discouraged consumption of raw or undercooked meats, which likely contributed to the decline in $T$. gondii infections from meat consumption (24).

In addition, the technology of livestock farming has improved management and reduced pathogenic animal infections, making meat safer. In Brazil, to prevent foodborne diseases, the Ministry of Agriculture, Livestock and Supply, through Administrative Rule no. 46, of February 10, 1998, adopted the hazard analysis and critical control point system as a prerequisite to export meat and to improve good production practices (25). In addition, manufacturers improved the practice of freezing meats, to either $-10^{\circ} \mathrm{C}$ degrees for 3 days or $-20^{\circ} \mathrm{C}$ degrees for 2 days, which sufficiently inactivates cysts (26). After the improvements in the system, the country saw a reduction in seropositivity to $T$. gondii over the intervening years (8).

We noted that consumption of undercooked game meat, such as reindeer, tapir, venison, wild boar, and armadillo, was the cause of Toxoplasma infection in several outbreaks globally (27-30). Studies have demonstrated that the unusual abundance of atypical T. gondii strains found in the wild can cause human toxoplasmosis in its most severe form, even in immunocompetent persons (16,27,29-33). The increased severity is caused by poor host adaptation to the circulating $T$. gondii zoonotic neotropical strains (27). In 2009, Pino et al. (32) described severe cardiac involvement in a military man who consumed untreated water during an operation in the jungle.

In addition, Carme et al. (27) reported 16 cases of severe toxoplasmosis in immunocompetent patients hospitalized with nonspecific infectious diseases in French Guiana. Many had severe pulmonary involvement (87.5\%), and $\geq 1$ had visceral alteration. T. gondii was isolated from 3 patients and characterized as an atypical genotype. Investigators determined game meat was the source of infection in $31.25 \%(5 / 16)$ of cases, likely through consumption of tissue cysts.

Infection through milk consumption was described in 3 outbreaks during 1975-1988, all of which affected intrafamily groups who consumed raw goat milk (34-36). Goats are known to secrete tachyzoites in milk $(37,38)$, and tachyzoites are resistant to processing in fresh cheeses (39). Standard measures to prevent Listeria monocytogenes, Brucella spp., and Mycobacterium spp. contamination in milk also reduce the risk for human $T$. gondii infection. Practices applied in milk production, such as pasteurization and brucellosis and tuberculosis prevention programs, likely have reduced incidence rates of $T$. gondii infection. We saw fewer outbreaks associated with contaminated milk in the 1990s and 2000s. 


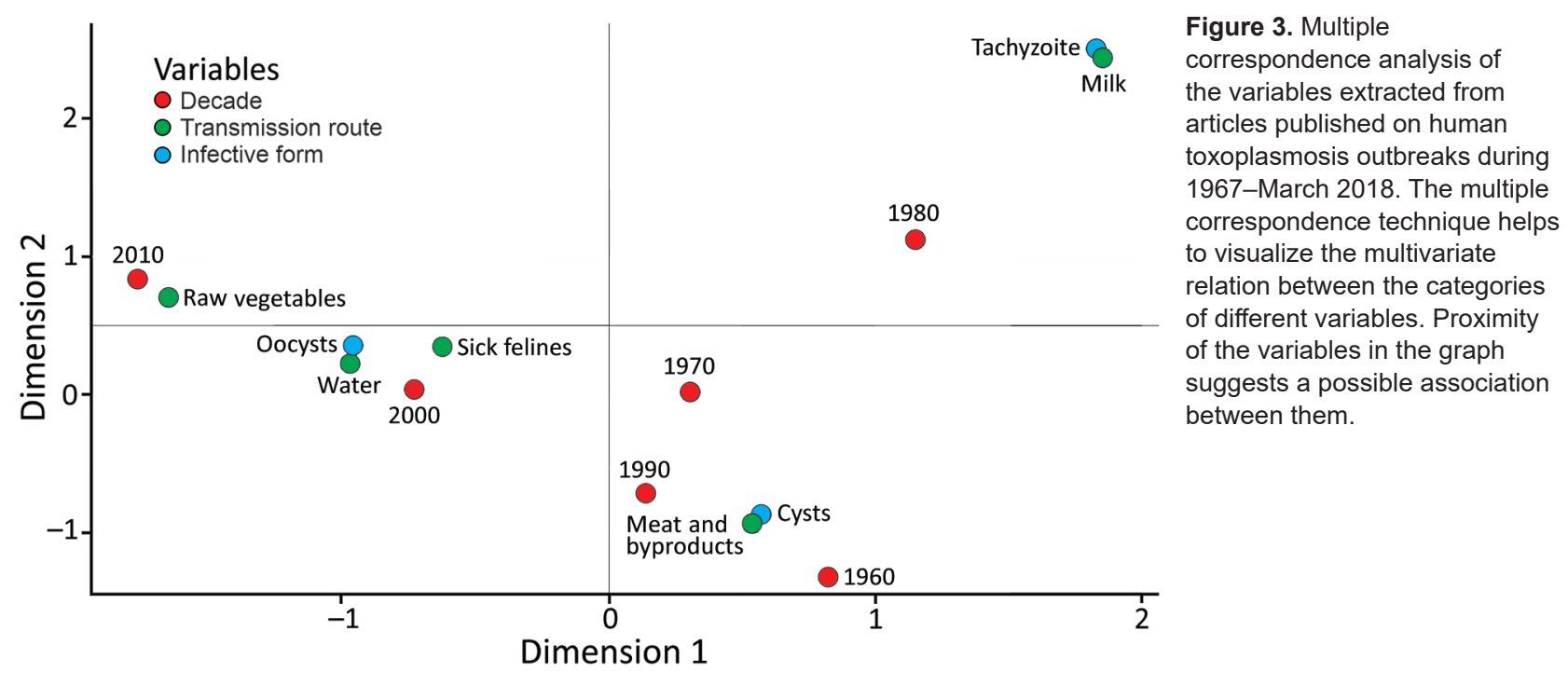

The outbreak in Santa Isabel do Ivaí (10) is notable in the history of toxoplasmosis, not only for the high number of cases but also because $T$. gondii was isolated directly from the transmission source, unfiltered municipal water. After this incident, outbreaks were investigated with more attention to this biologic form, a factor that might explain the increase of detected outbreaks of water origin.

One of the main forms of transmission of toxoplasmosis is the fecal-oral route. Felines, definitive hosts for $T$. gondii, eliminate the oocysts in the environment, where they can remain viable for several months in appropriate conditions and cause infection (2). Because cats defecate in soil and sand, contact with these sources is a risk factor for infection. Contact with soil and sand was the transmission route in $17.6 \%(6 / 34)$ of human outbreaks reported; $67.0 \%$ of those affected were children or adolescents, probably because children play in these environments and indirectly consume oocysts.

In the past 20 years, consumption of healthy foods, such as vegetables, has increased through efforts to change eating habits and combat obesity (40). Vegetables provide micronutrients and fiber, which aid in maintaining body weight (41). However, increasing reports of toxoplasmosis have coincided with increased consumption of fruits and vegetables. Toxoplasmosis outbreaks related to vegetables generally occurred because of contamination during the production, including planting, harvesting, transport, and distribution, but also during processing and consumption (42). In 2009, an investigation of a cluster of 11 cases of acute toxoplasmosis in a factory with 2,300 employees in São Paulo State, Brazil, revealed vegetable ingestion as the suspected transmission route (43). In 2013, the municipality of Ponta de Pedras in Pará State, Brazil, was the scene of an outbreak of toxoplasmosis involving 73 cases with clinical and laboratory findings compatible with the disease. Açaí consumption was identified as the source of the infections. Ponta de Pedras is one of the main producers of açaí in Brazil, but the outbreak occurred during the period when local production of açaí was practically nil. To satisfy the population's demand for the fruit, açaí vendors acquired the fruit from other locations, where it might have been contaminated with atypical $T$. gondii strains for which the urban population had little immunity (44).

Such events demonstrate the inadequate sanitation in industrial settings and restaurants and lack of quality control of commercial produce common in developing countries. Considering the increased attention given to safety for food of animal origin in recent years, and the concomitant increase in consumption of raw vegetables and fruits, foods contaminated by oocysts could become the main source for toxoplasmosis outbreaks.

When reviewing the number of cases in toxoplasmosis outbreaks, we noted that oocysts were responsible for outbreaks with high case counts, such as those occurring in city districts or entire municipalities. Although reported outbreaks due to oocysts and cysts occurred at similar rates, outbreaks from oocysts affected many more persons $(>1,400)$ than did outbreaks due to cysts $(\approx 290$ persons $)$. Contaminated drinking water was responsible for the largest outbreak of toxoplasmosis described (16), but water also serves as a contamination route for vegetables and fruits when used in irrigation $(16,44,45)$. Domestic and wild felids are known to have seroprevalence for $T$. gondii, and a single cat can eliminate $>100$ million oocysts into the environment after primary infection $(46,47)$. Such shedding can lead to water dispersion and large-scale outbreaks (Appendix). Cyst infection appears to affect fewer persons in intrafamilial or party-restricted outbreaks $(48,49)$.

Public health prevention efforts for toxoplasmosis frequently focus on congenital infections to reduce the 
risk of miscarriage in pregnant women. However, with the occurrence of outbreaks in immunocompetent humans, we suggest that infection control and health education also should be directed to the rest of the population. According to World Health Organization estimates, toxoplasmosis is among the leading foodborne parasitic diseases and in recent years has affected $>10.3$ million persons worldwide (50). Because toxoplasmosis is not a notifiable disease in most countries, reports of toxoplasmosis outbreaks in the literature are needed to increase our understanding of transmission and help reduce the number of outbreaks.

Through our review of published data, we believe the epidemiology of reported toxoplasmosis outbreaks has changed over the past 20 years. Consequently, we suggest that greater attention be paid to the production and disinfection of vegetables, to the quality of drinking and irrigation water, and to the adoption of legislation for tracking outbreaks with the aim of eliminating transmission routes, avoiding exposure, or inactivating the parasite before consumption.

\section{About the Author}

Dr. Pinto-Ferreira is a professor of veterinary parasitology at the State University of Londrina, Brazil. Her research interests include experience in preventive veterinary medicine, mainly in the areas of geoprocessing applied to public health, epidemiology, and environmental protozoology, toxoplasmosis, giardiasis, cryptosporidiosis, and investigation of waterborne and foodborne outbreaks.

\section{References}

1. Jacobs L. The interrelation of toxoplasmosis in swine, cattle, dogs, and man. Public Health Rep. 1957;72:872-82. https://doi.org/10.2307/4589927

2. Dubey JP, Miller NL, Frenkel JK, Frenkel AJK. The Toxoplasma gondii oocyst from cat feces. J of Exp Med. 1970;132:636-62. https://doi.org/10.1084/jem.132.4.636

3. Tenter AMM, Heckeroth ARR, Weiss LMM. Toxoplasma gondii: from animals to humans. Int J Parasitol. 2000;30:1217-58 . https://doi.org/10.1016/s0020-7519(00)00124-7

4. Dubey JP. Toxoplasma, Hammondia, Besnoitia, Sarcocystis and others tissue cyst-forming coccidia of man and animals. In: Kreier JP, ed. Parasitic Protozoa. 3rd ed. New York: Academic Press; 1977. p. 101-237.

5. Magaldi C, Elkis H, Pattoli D, de Queiróz JC, Coscina AL, Ferreira JM. Outbreak of toxoplasmosis in a Paulist seminary in Braganza (São Paulo state). Clinical, serological and epidemiological aspects [in Portuguese]. Rev Saude Publica. 1967;1:141-71. https://doi.org/10.1590/S0034-89101967000200003

6. Dean AG, Dean JA, Burton AH, Discker RC. Epi-Info: a word processing, database, and statistics program for epidemiology on microcomputers, version 5. Atlanta: Centers for Disease Control and Prevention; 1990.

7. Lebart L, Morineau A, Warwick KM. Multivariate descriptive statistical analysis; correspondence analysis and related techniques for large matrices. New York, New York: John Wiley \& Sons; 1984.

8. Dubey JP, Lago EG, Gennari SM, Su C, Jones JL. Toxoplasmosis in humans and animals in Brazil: high prevalence, high burden of disease, and epidemiology. Parasitology. 2012;139:1375-424 https://doi.org/10.1017/S0031182012000765

9. Petersen E, Vesco G, Villari S, Buffolano W. What do we know about risk factors for infection in humans with Toxoplasma gondii and how can we prevent infections? Zoonoses Public Health. 2010;57:8-17. https://doi.org/10.1111/j.1863-2378.2009.01278.x

10. Sibley LD, Boothroyd JC. Virulent strains of Toxoplasma gondii comprise a single clonal lineage. Nature. 1992;359:82-5. https://doi.org/10.1038/359082a0

11. Howe DK, Sibley LD. Toxoplasma gondii comprises three clonal lineages: correlation of parasite genotype with human disease. J Infect Dis. 1995;172:1561-6. https://doi.org/10.1093/infdis/172.6.1561

12. Shwab EK, Zhu X-Q, Majumdar D, Pena HFJ, Gennari SM, Dubey JP, et al. Geographical patterns of Toxoplasma gondii genetic diversity revealed by multilocus PCR-RFLP genotyping. Parasitology. 2014;141:453-61. https://doi.org/10.1017/ S0031182013001844

13. Su C, Khan A, Zhou P, Majumdar D, Ajzenberg D, Darde M-L, et al. Globally diverse Toxoplasma gondii isolates comprise six major clades originating from a small number of distinct ancestral lineages. Proc Natl Acad Sci USA. 2012;109:5844-9. https://doi.org/10.1073/pnas.1203190109

14. Dubey JP, Lago EG, Gennari SM, Su C, Jones JL. Toxoplasmosis in humans and animals in Brazil: high prevalence, high burden of disease, and epidemiology. Parasitology. 2012;139:1375-424. https://doi.org/10.1017/S0031182012000765

15. De Salvador-Guillouët F, Ajzenberg D, Chaillou-Opitz S, Saint-Paul MC, Dunais B, Dellamonica P, et al. Severe pneumonia during primary infection with an atypical strain of Toxoplasma gondii in an immunocompetent young man. J Infect. 2006;53: e47-50. https://doi.org/10.1016/j.jinf.2005.10.026

16. de Moura L, Bahia-Oliveira LMG, Wada MY, Jones JL, Tuboi SH, Carmo EH, et al. Waterborne toxoplasmosis, Brazil, from field to gene. Emerg Infect Dis. 2006;12:326-9. https://doi.org/10.3201/ eid1202.041115

17. Ponte S, Burguez D, Adrioli G. Outbreak of toxoplasmosis in the city of Santa Maria, Brazil. Prehosp. Disaster Med. 2019;34(Suppl. 1):s74. https://doi.org/10.1017/S1049023X19001602

18. Bonametti AM, Passos JN, da Silva EM, Bortoliero AL. Outbreak of acute toxoplasmosis transmitted thru the ingestion of ovine raw meat [in Portuguese]. Rev Soc Bras Med Trop. 1997;30:21-5. https://doi.org/10.1590/S0037-86821997000100005

19. Renoiner EIM, Siqueira AA, Garcia MH, Alves RM, Cardoso ME, Ferreira ABPL, et al. Outbreak of acquired toxoplasmosis, Anápolis-GO, February 2006 [in Porutguese]. Boletim eletrônico epidemiológico da secretária de vigilância em saúde. 2007;(8):1-6 [cited 2019 Oct 13]. https://portalarquivos2.saude.gov.br/images/ pdf/2014/julho/16/Ano07-n08-toxoplasmose-adquirida-go-completo.pdf

20. Fertig A, Selwyn S, Tibble MJ. Tetracycline treatment in a food-borne outbreak of toxoplasmosis. Br Med J. 1977;1:1064. https://doi.org/10.1136/bmj.1.6068.1064

21. Masur H, Jones TC, Lempert JA, Cherubini TD. Outbreak of toxoplasmosis in a family and documentation of acquired retinochoroiditis. Am J Med. 1978;64:396-402. https://doi.org/ 10.1016/0002-9343(78)90218-8

22. De Silva LM, Mulcahy DL, Kamath KR. A family outbreak of toxoplasmosis: a serendipitous finding. J Infect. 1984;8:163-7. https://doi.org/10.1016/S0163-4453(84)92617-3

23. Dubey JP, Kotula AW, Sharar A, Andrews CD, Lindsay DS Effect of high temperature on infectivity of Toxoplasma gondii tissue cysts in pork. J Parasitol. 1990;76:201-4. https://doi.org/10.2307/3283016

24. Ministry of Health, Brazil. Project for the control of the teniasis/ cysticercosis complex in Brazil [in Portuguese]. Brasília (Brazil): The Ministry; 1996. 
25. Rossi GAM, Hoppe EGL, Martins AMCV, Prata LF. Foodborne parasitic zoonosis: a review of the situation in Brazil [in Portuguese]. Arq Inst Biol (Sao Paulo). 2014;81:290-8 https://doi.org/10.1590/1808-1657000742012

26. El-Nawawi FA, Tawfik MA, Shaapan RM. Methods for inactivation of Toxoplasma gondii cysts in meat and tissues of experimentally infected sheep. Foodborne Pathog Dis. 2008;5: 687-90. https://doi.org/10.1089/fpd.2007.0060

27. Carme B, Bissuel F, Ajzenberg D, Bouyne R, Aznar C, Demar M, et al. Severe acquired toxoplasmosis in immunocompetent adult patients in French Guiana. J Clin Microbiol. 2002;40:4037-44. https://doi.org/10.1128/JCM.40.11.4037-4044.2002

28. Choi WY, Nam HW, Kwak NH, Huh W, Kim YR, Kang MW, et al. Foodborne outbreaks of human toxoplasmosis. J Infect Dis. 1997;175:1280-2. https://doi.org/10.1086/593702

29. Sacks JJ, Delgado DG, Lobel HO, Parker RL. Toxoplasmosis infection associated with eating undercooked venison. Am J Epidemiol. 1983;118:832-8. https://doi.org/10.1093/oxfordjournals.aje.a113701

30. McDonald JC, Gyorkos TW, Alberton B, MacLean JD, Richer G, Juranek D. An outbreak of toxoplasmosis in pregnant women in northern Québec. J Infect Dis. 1990;161:769-74. https://doi.org/10.1093/infdis/161.4.769

31. Sobanski V, Ajzenberg D, Delhaes L, Bautin N, Just N. Severe toxoplasmosis in immunocompetent hosts: be aware of atypical strains. Am J Respir Crit Care Med. 2013;187:1143-5. https://doi.org/10.1164/rccm.201209-1635LE

32. Pino LE, Salinas JE, López MC. Description of an epidemic outbreak of acute toxoplasmosis in immunocompetent patients from Colombian Armed Forces during jungle operations. Infectio. 2009;13:83-91. https://doi.org/10.1016/S0123-9392(09)70729-5

33. Demar M, Ajzenberg D, Maubon D, Djossou F, Panchoe D, Punwasi W, et al. Fatal outbreak of human toxoplasmosis along the Maroni River: epidemiological, clinical, and parasitological aspects. Clin Infect Dis. 2007;45:e88-95. https://doi.org/10.1086/521246

34. Skinner LJ, Timperley AC, Wightman D, Chatterton JMW, Ho-Yen DO. Simultaneous diagnosis of toxoplasmosis in goats and goatowner's family. Scand J Infect Dis. 1990;22:359-61. https://doi.org/10.3109/00365549009027060

35. Sacks JJ, Roberto RR, Brooks NF. Toxoplasmosis infection associated with raw goat's milk. JAMA. 1982;248:1728-32. https://doi.org/10.1001/jama.1982.03330140038029

36. Chiari CA, Neves DP. Human toxoplasmosis acquired by ingestion of goat's milk [in Portuguese]. Mem Inst Oswaldo Cruz. 1984; 79:337-40. https://doi.org/10.1590/S0074-02761984000300007

37. Bezerra MJG, Kim PCP, Moraes ÉPBX, Sá SG, Albuquerque PPF, Silva JG, et al. Detection of Toxoplasma gondii in the milk of naturally infected goats in the northeast of Brazil. Transbound Emerg Dis. 2015;62:421-4. https://doi.org/10.1111/tbed.12160

38. Spišák F, Turčeková, Reiterová K, Špilovská S, Dubinský P. Prevalence estimation and genotypization of Toxoplasma gondii in goats. Biologia. 2010;65:670-4. https://doi.org/10.2478/ s11756-010-0070-2

39. Dubey JP, Verma SK, Ferreira LR, Oliveira S, Cassinelli AB, Ying Y, et al. Detection and survival of Toxoplasma gondii in milk and cheese from experimentally infected goats. J Food Prot. 2014;77:1747-53. https://doi.org/10.4315/0362-028X.JFP-14-167

40. Ministry of Health, Brazil. Surveillance of risk factors and protection for chronic diseases by telephone inquiry [in
Portuguese] [Internet]. Brasília (Brazil): The Ministry; 2016 [cited 2019 Oct 11]. http://bvsms.saude.gov.br/bvs/publicacoes/ vigitel_brasil_2016_saudesuplementar.pdf

41. Ministry of Health, Brazil. Obesity grows $60 \%$ in ten years in Brazil [in Portuguese] [Internet]. Brasília (Brazil): The Ministry; 2016 [cited 2017 Nov 13]. http://www.brasil.gov.br/saude/2017/04/ obesidade-cresce-60-em-dez-anos-no-brasil

42. Ferreira FP, Caldart ET, Freire RL, Mitsuka-Breganó R, Freitas FM, Miura AC, et al. The effect of water source and soil supplementation on parasite contamination in organic vegetable gardens. Rev Bras Parasitol Vet. 2018;27:327-37. https://doi.org/ 10.1590/s1984-296120180050

43. Ekman CC, Chiossi MF, Meireles LR, Andrade Júnior HF, Figueiredo WM, Marciano MA, et al. Case-control study of an outbreak of acute toxoplasmosis in an industrial plant in the state of São Paulo, Brazil [in Portuguese]. Rev Inst Med Trop Sao Paulo. 2012;54(5):239-44. https://doi.org/10.1590/ s0036-46652012000500001

44. Morais RAPB, Freire ABC, Barbosa DRL, Silva LCT, Pinheiro AF, Costa SS, et al. Acute toxoplasmosis outbreak in the Municipality of Ponta de Pedras, Marajó archipelago, Pará State, Brazil: clinical, laboratory, and epidemiological features [in Portuguese]. Revista Pan-Amazônica de Saúde. 2016;7(esp):143-52. https://doi.org/10.5123/S2176-62232016000500016

45. Dutra LH, Saad E, Alves RM S, Cabral CM, Batista FS, de Lima R, et al. Investigation of an outbreak of toxoplasmosis transmitted by açaí consumption in Rondônia, Brazil, 2011 [in Portuguese]. Annals of the 12th EXPOEPI. Brasília: Ministry of Health; 2012. p. 108-9.

46. Silva JCR, Ogassawara S, Adania CH, Ferreira F, Gennari SM, Dubey JP, et al. Seroprevalence of Toxoplasma gondii in captive neotropical felids from Brazil. Vet Parasitol. 2001;102:217-24. https://doi.org/10.1016/S0304-4017(01)00523-4

47. Innes EA, Bartley PM, Maley S, Katzer F, Buxton D. Veterinary vaccines against Toxoplasma gondii. Mem Inst Oswaldo Cruz. 2009;104:246-51. http://dx.doi.org/10.1590/S0074-02762 009000200018

48. Almeida MABA, Alencar Júnio LR, Carmo GMI, Araújo WNA, Garcia MHO, Reis AK V, et al. Intra-family outbreak of toxoplasmosis, Santa Vitória do Palmar-RS, July 2005 [in Portuguese]. Boletim eletrônico epidemiológico da secretária de vigilância em saúde. 2006;18(3):1-7.

49. Eduardo MB de P, Katsuya EM, Ramos SRTS, Pavanello EI, Paiva OR, Brito S do N, et al. Investigation of the outbreak of toxoplasmosis associated with the consumption of raw meat dish ("steak tartar"), in the municipalities of São Paulo and Guarujá, $\mathrm{SP}$-November 2006 [in Portuguese]. Boletim Epidemiológico Paulista. 2007;4:1-6.

50. Torgerson PR, Devleesschauwer B, Praet N, Speybroeck N, Willingham AL, Kasuga F, et al. World Health Organization estimates of the global and regional disease burden of 11 foodborne parasitic diseases, 2010: a data synthesis. PLoS Med. 2015;12:e1001920. https://doi.org/10.1371/journal. pmed. 1001920

Address for correspondence: Fernanda Pinto-Ferreira, Universidade Estadual de Londrina Centro de Ciencias Agrarias, PR, Km 380, 86.057-970 Paraná, Londrina, Brazil; email: fernandaferreira@uel.br 